Note

\title{
ECONOMIC VIABILITY OF THE PIAUÇU Leporinus macrocephalus (Garavello \& Britski, 1988) PRODUCTION
}

\author{
Leonardo Susumu Takahashi ${ }^{1 *}$; Flavio Daolio Gonçalves²; Janessa Sampaio de Abreu²; Maria \\ Inez Espagnoli Geraldo Martins ${ }^{2,3}$; Antonio Carlos Manduca Ferreira ${ }^{3,2}$ \\ ${ }^{1}$ UNESP/FCAV - Depto. de Morfologia e Fisiologia Animal - 14884-900 - Jaboticabal, SP - Brasil. \\ ${ }^{2} U N E S P / C A U N E S P$ - Centro de Aqüicultura da UNESP. \\ ${ }^{3}$ UNESP/FCAV - Depto. de Economia Rural. \\ *Corresponding author <lstakahashi@asbyte.com.br>
}

\begin{abstract}
Brazilian fish farms presented an accelerated development during the early 90's, mainly because of the increase in fee-fishing operations. To meet the demand of this market, fish production and supply became excessive and, as a consequence, the number of fee-fishing operations, farmers and the final selling price, decreased. This study analyzes the technical aspects, production cost, profitability and economic viability of the production of piauçu ( $L$. macrocephalus) in ponds, based on information from a rural property. Feeding and fingerling costs amount to approximately $47.1 \%$ of the total production cost, representing together with the final selling price the most important factor affecting profitability. The payback period was 8.3 years, the liquid present value US\$291.07, the internal return margin $9 \%$, and the income-outcome ratio was 1.01 , which represents an unattractive investment as a projection based on current conditions. The improvement in productive efficiency enhances the economic valuation index, and that the relative magnitude of cost and income are the most important points for the economic viability of the studied farm.

Key words: costs, profitability, economic analysis, sensitivity analyses, fish farming
\end{abstract}

\section{VIABILIDADE ECONÔMICA DA PRODUÇÃO DE PIAUÇU Leporinus macrocephalus (Garavello \& Britski, 1988)}

\begin{abstract}
RESUMO: A piscicultura brasileira apresentou um acelerado desenvolvimento nos anos 90, principalmente impulsionada pelo aumento de estabelecimentos pesqueiros conhecidos como "pesque-pagues". Entretanto, o aumento do número de criadores de alevinos e a redução de pesqueiros resultou em um aumento na oferta de peixes e, conseqüente, diminuição do preço de comercialização. O presente estudo analisa os parâmetros zootécnicos, os custos de produção, a rentabilidade e a viabilidade econômica da engorda de piauçu ( $L$. macrocephalus) em tanques escavados. Os custos com insumos somam 47,1\% do custo total de produção, representando juntamente com o preço de venda do pescado, o fator decisivo na rentabilidade da atividade. $\mathrm{O}$ período de recuperação do capital foi de 8,3 anos, valor presente líquido de US\$291,07, taxa interna de retorno de $9 \%$ e relação benefício-custo de 1,01. Como projeto, nas condições atuais, trata-se de um investimento de baixa atratividade. $\mathrm{O}$ aumento da eficiência produtiva melhorou os índices de avaliação econômica e o acompanhamento dos custos e receitas é ponto fundamental para a viabilidade econômica da propriedade estudada.

Palavras-chave: custo de produção, rentabilidade, análise econômica, análise de sensibilidade, piscicultura
\end{abstract}

\section{INTRODUCTION}

Aquaculture has been established in Brazil as an economic activity only since the mid 1980s. Such a consolidation occurred, among other factors, as a consequence of the development of production technologies suitable for rational production systems, both in large and small scales, which allowed product outputs (Martin et al., 1995).

Aquaculture has been stimulated by private fishing activities, called fee-fishing. In the State of São Paulo,
Brazil, these activities spread quickly, mostly around large urban centers, increasing from only a few properties in the early 1990 s to more than 1,500 in 1997 . The increased demand induced by fee-fishing operations affected the aquaculture productive chain by increasing numbers of fisheries and input producers, improving fish rearing technology and increasing productivity (Scorvo Filho, 1998).

The fee-fishing industry absorbed more than $90 \%$ of the captivity-raised fish from the state. However, fish farming increased excessively as compared to the demand for fee-fishing, thus resulting in a current excess supply. 
Thus, as the growth in fee-fishing activities has stabilized, fish farmers should look for other market possibilities, despite the risk of incurring reduced product price.

Because of the scarce literature on economical feasibility of aquaculture activities, case studies are still very helpful, improving understanding of a problem and identifying informative situations (Antonialli \& Galan, 1997). Case studies also aid in agribusiness education and support to fishery industry. Such studies have been used in most of the modern universities, constituting the basis and fundamentals for research, teaching and extension (Zylbersztajn, 1993).

Because of the current need for technical and economical efficiency in production, many studies have been carried out to provide theoretical and practical backgrounds for the administration of agricultural properties, specially dairy cattle (Mancio et al., 1999; Oliveira et al., 2001; Holanda Jr. et al., 2002) and swine farming (Leite et al., 2001), each with specificities and details. In regard to aquaculture, some studies investigated the fishes tilapia, pacu and carp under different production systems (Martin et al., 1995; Chabalin \& Neves, 1997; Scorvo Filho et al., 1998; Carneiro et al., 1999; Hermes et al., 2000 ), each of them providing valuable management contributions to this complex activity. This study evaluated costs, profitability and economic viability of pond farming of piauçu fish (Leporinus macrocephalus).

\section{MATERIAL AND METHODS}

Through semi-structured interviews and cost marks, a fish farm owner provided information for the estimation of animal-production parameters and for economic analyses. This legally registered farm is situated

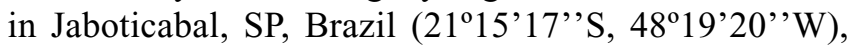
raises fish since 1998 and the reported data is from the 2000/2001 period. In the first year, a specialized technician assisted in the project, planning and implementation.

The production structure consists of seven circular earthen ponds $\left(706.8 \mathrm{~m}^{2}\right.$ each) with cement walls, and two square ponds $\left(400 \mathrm{~m}^{2}\right.$ each), approaching 0.97 ha of water surface. Well water continuously supplies the ponds throughout the year, except in the winter when water restriction is necessary.

Four to 7-cm juveniles were obtained from commercial hatcheries located about $30 \mathrm{~km}$ from the farm and fed exclusively commercial balanced diet. The main commercialized fish is piauçu (Leporinus macrocephalus), which has an annual production cycle. Stocking density used for grow out is about $2 \mathrm{~kg}$ fresh fish $\mathrm{m}^{-2}$, the market fresh body weight is about $1 \mathrm{~kg}$, the total survival rate is $83 \%$ and feed conversion rate (FCR) is 2.44 .

The annual production of piauçu ( $\cong 20 \mathrm{t}$ ), represents productivity index of $20.6 \mathrm{tha}^{-1}$ and is completely directed to regional fee-fishing operations. The owner himself commercializes the fish gradually as they reach market size, while the remainder stay in the ponds for further growth.

Economic evaluation data were corrected by a General Price Index (IGP-DI) from January 2001, provided by Fundação Getúlio Vargas. For cost determination, the Operational Production Cost model proposed by Matsunaga et al. (1976), and the Total Production Cost model were utilized. In the first model, effective owner expenses within the productive cycle (input and materials, manpower, machine implementation, operation and repairs) and lag values for machinery depreciation, equipment and specific infrastructures were considered.

For calculation of the Total Production Cost, besides the above items, the opportunity cost of the applied capital (cycling capital interest costs and the remuneration of fixed, land and entrepreneurial capital) was also considered. The technical coefficients for labor, equipment and inputs were obtained directly from the producer. For labor determination, a single worker that accounted for activity throughout the whole year with a monthly payment of US\$ 117.65 and $43 \%$ of social tax was considered. As eventual manpower the need for five workers during harvest was considered (harvesting fish from 2 ponds per day) each paid US\$ 7.67 day $^{-1}$. For feedstuff evaluation, all the feed types of each production phase were considered, and prices refer to the mean price for $\mathrm{Jan} / \mathrm{Feb}$ 2001. The producer reported the cost of the remaining items.

Linear depreciation was applied for equipment and infrastructure (Noronha, 1981) considering their shelf life and the updated initial acquisition/building price. Ten percent of the equipment value and $2 \%$ of the improvement per year were also assumed as maintenance tax.

The farmer used his own resources to implement and maintain the farm. For assessment of the total production cost, a $8.75 \%$ year $^{-1}$ tax was considered (over $50 \%$ of the expenses) for calculating the interest on the cycling capital. This tax contains the rural credit for supporting agricultural loans. Remuneration of the fixed capital considered the mean capital value to be remunerated at $6 \%$ per year, which corresponds to the real saving remuneration. Land remuneration was based on the mean rental value of 1 ha for sugarcane crop in Jaboticabal, SP Brazil (Instituto de Economia Agrícola, 2002). Farmer's remuneration was stipulated as 24 minimum wages (US\$ 92.07) per year.

The decision making for investments should analyze indicators for the return on the economic investment. For this analysis, a cash inflow was calculated based on annual inputs and outputs throughout the considered period (12 years). This is the recommended period for pond renovations or rebuilding, which were the main investment for improvements of the infrastructure on the studied farm. The output flows at the beginning (time zero) 
were derived from implementation investments already made, but for subsequent years refer to equipment replacement due to the end of their shelf life. The other annual outputs were operational expenses, which are the effective operational cost of the land and other taxes. A discount rate of $8.75 \%$ was applied corresponding to the agricultural loan provided by the bank (Banco do Brasil).

The investment feedback was analyzed from the cash inflow using the following calculations:

a) Capital payback period (Payback: $\sum_{t=0}^{n} L t=0$, where $n$ $\leq$ project horizons; $L t=$ project annual inflow; and $n$ $=$ capital payback period);

b) Net present value $\left(\mathrm{NPV}=\sum_{t=0}^{N} \frac{L t}{(1+p)^{t}}\right.$, where $N=$ project horizon; and $p=$ discount ratio); c) Internal rate of return $\left(\operatorname{IRR}: \sum_{t=o}^{N} L t\left(1+p^{*}\right)^{-t}=0\right.$,
$\mathrm{p}^{*}=$ internal pay-back rate;

d) benefit cost ratio $\left(\mathrm{BCR}=\frac{\sum_{t=1}^{N} L t(1+p)^{-t}}{L_{0}}\right.$ ).

These variables were proposed by Noronha (1981), Scorvo Filho et al. (1998), and Holanda Jr. et al. (2000) for agricultural and aquaculture project evaluations.

The project risk was evaluated by a sensitivity analyses, that is, by changing values of the most significant variables for cost and incomes (Gitman, 1997). In this way, in the sensitivity analyses 1 and 2 the cost of feeding was changed; in analysis 3 , the fish selling price (per $\mathrm{kg}$ ) was altered; and in analysis 4 , the survival rate was increased to $85 \%$ and the feeding conversion ratio improved (to 1.9); costs with production and technical assistance were increased and feeding costs decreased.

\section{RESULTS AND DISCUSSION}

The values found for the production cycle, survival rate and growth density in the fish farm were, as expected, specific for this type of production system. However, the feed conversion rate (FCR) was not satisfactory, because other produced tropical species, such as carp, pacu, tambaqui and Brycon sp., when reared in cages with low water renovation and fed with complete diet, presented expected survival rates around $90 \%$ and feeding conversions between 1.9 and 2.2 (Kubitza, 1999).

The production cycle for fishes, such as tambaqui and pacu, is about 13 months, with FCR of 1.8, survival rate of $90 \%$ and annual income of 11.70 ton $\mathrm{ha}^{-1}$. For carps, however, the production cycle is 12 months, with FCR of 1.3 , survival rate of $85 \%$ and annual income of 12.75 ton $\mathrm{ha}^{-1}$ (Scorvo Filho et al., 1998). Thus, production of $20,000 \mathrm{~kg}_{\text {year }}{ }^{-1}$ and productivity of $20.6 \mathrm{t} \mathrm{ha}^{-1}$ obtained in the studied farm are higher than those reported for other tropical fish.

Costs for the aquaculture implementation in the studied farm are presented in Table 1. The largest investment was for the construction of the ponds and consisted of $41.1 \%$ of the total implementation cost. This cost was not higher because the farmer already owned the land. Inputs were the most significant in the total production cost (about 46\%; Table 2), mainly regarding feeds and fingerlings. Thus, any percentile variation in prices of these inputs directly affects the total production cost. The capital depreciation, upkeeping and wages were calculated from the first values of equipment and buildings. These inputs are very significant because they represent $20 \%$ of the whole production cost.

In 2001, the total operational cost was US\$ $23,237.87$ and the total production cost US\$ $1.39 \mathrm{~kg}^{-1}$ (Table 3). In 1996, the operational costs for pacu production in Ribeirão Preto, SP, Brazil, were US\$ 24,019.95 year $^{-1}$ (Chabalin \& Neves, 1997). In the 1996-1997 crop, the pacu and tambaqui production from the São Paulo State implied in an effective operational cost of US\$ 0.64 per $\mathrm{kg}$ of fish, a total operational cost of US\$ 0.96 per $\mathrm{kg}$ and a total production cost of US\$ 1.04 per $\mathrm{kg}$. According to Scorvo Filho et al. (1998), for the common carp, values are: effective operational cost $=$ US $\$ 0.64$ $\mathrm{kg}^{-1}$; total operational cost $=$ US $\$ 0.78 \mathrm{~kg}^{-1}$; and total production cost $=$ US\$ $1.13 \mathrm{~kg}^{-1}$. Different species were used for these reported values, and different aquaculture pro-

Table 1 - Costs for implementation of a piauçu (Leporinus macrocephalus) farm. Currency values date from $\mathrm{Jan} / 2001$.

\begin{tabular}{lrc}
\hline Item & & Share \\
\hline & US $\$$ & $\%$ \\
Project & & \\
Legal fess & 767.26 & 1.85 \\
Register & 63.94 & 0.15 \\
Technic assistance & $1,104.86$ & 2.66 \\
\hline Infra structure & & \\
Housing & $8,192.88$ & 19.72 \\
Storage & $5,461.92$ & 13.14 \\
\hline Productive area & & \\
Ponds & $17,068.51$ & 41.07 \\
\hline Equipment & & \\
Oxymeter & $1,228.93$ & 2.96 \\
Balance & 68.28 & 0.16 \\
Aerators (1) & $4,369.54$ & 10.51 \\
\hline Aerators (2) & $2,389.59$ & 5.75 \\
Net & 819.29 & 1.97 \\
Wheelbarrow & 20.48 & 0.05 \\
\hline TOTAL & $41,555.47$ & 100.00 \\
\hline
\end{tabular}


Table 2 - Distribution of production costs for production of piauçu (L. macrocephalus) in 0.97 ha of water. Currency value date from Jan/2001.

\begin{tabular}{|c|c|c|}
\hline & Cost & Share \\
\hline & US\$ & $\%$ \\
\hline \multicolumn{3}{|l|}{ Input } \\
\hline $1,250 \mathrm{~kg}$ - Initial & 276.21 & 1.0 \\
\hline $10,000 \mathrm{~kg}-32 \% \mathrm{CP}$ & $2,864.45$ & 10.3 \\
\hline $37,500 \mathrm{~kg}-28 \% \mathrm{CP}$ & $8,746.80$ & 31.6 \\
\hline Fingerlings & $1,150.90$ & 4.2 \\
\hline \multicolumn{3}{|l|}{ Labour } \\
\hline Permanet & $2,187.06$ & 7.9 \\
\hline Fish-harvest & 191.82 & 0.7 \\
\hline Night guardian & 409.21 & 1.5 \\
\hline \multicolumn{3}{|l|}{ Upkeeping } \\
\hline oxymeter & 122.89 & 0.4 \\
\hline balance & 6.83 & $<0.1$ \\
\hline aerators (1) & 436.95 & 1.6 \\
\hline aerators (2) & 238.96 & 0.9 \\
\hline net & 81.93 & 0.3 \\
\hline wheelbarrow & 2.05 & $<0.1$ \\
\hline housing & 163.86 & 0.6 \\
\hline storage & 109.24 & 0.4 \\
\hline ponds & 341.37 & 1.2 \\
\hline Fuel & 446.09 & 1.6 \\
\hline Energy supply & $1,636.83$ & 5.9 \\
\hline Telephone & 368.29 & 1.3 \\
\hline Register & 63.94 & 0.2 \\
\hline Rural Land Tax (ITR) & 3.45 & $<0.1$ \\
\hline Effective Operational Cost & $19,849.11$ & 71.6 \\
\hline Interests over cycling capital & 868.40 & 3.1 \\
\hline Variable Cost & $20,717.51$ & 74.7 \\
\hline \multicolumn{3}{|l|}{ Depreciation } \\
\hline oxymeter & 245.79 & 0.9 \\
\hline balance & 6.83 & $<0.1$ \\
\hline aerators (1) & 624.22 & 2.3 \\
\hline aerators (2) & 398.27 & 1.4 \\
\hline net & 273.10 & 1.0 \\
\hline wheelbarrow & 2.05 & $<0.1$ \\
\hline housing & 234.08 & 0.8 \\
\hline storage & 182.06 & 0.7 \\
\hline ponds & $1,422.38$ & 5.1 \\
\hline Toral Operational Cost & $23,237.87$ & 83.8 \\
\hline Land remuneration & 213.41 & 0.8 \\
\hline \multicolumn{3}{|l|}{ Capital remuneration } \\
\hline oxymeter & 36.87 & 0.1 \\
\hline balance & 2.05 & $<0.1$ \\
\hline aerators (1) & 131.09 & 0.5 \\
\hline aerators (2) & 71.69 & 0.3 \\
\hline net & 24.58 & 0.1 \\
\hline wheelbarrow & 0.61 & $<0.1$ \\
\hline housing & 245.79 & 0.9 \\
\hline storage & 163.86 & 0.6 \\
\hline ponds & 512.06 & 1.8 \\
\hline Entrepreneur remuneration & $2,209.72$ & 8.0 \\
\hline Fixed Costs & $7,000.47$ & 25.3 \\
\hline Total Production Cost & $27,717.98$ & 100.0 \\
\hline
\end{tabular}

duction systems usually do not share the same characteristics, thus emphasizing the importance of reporting case studies.

In relation to profitability, the producer got a positive net income because of practicing selling price higher than the average market price (US\$ 1.33), being able to afford the total operational cost, but without earnings, since the total production cost could not be covered. The positive financial net income indicates a short term return. However, the long term profit is not feasible because it could not afford the total production costs. This production cash inflow is shown in Table 4. Investments, expenses and incomes are relative to the outputs from the beginning of the fish farm (time zero). The other outputs were computed over 12 years and the other inputs from fish sold in the same period.

Considering the evaluated investments and incomes, in a 12-year project, this project presents a capital wage of 8.29 years, that is, the capital would be recovered only by the middle of the $9^{\text {th }}$ year (Table 5). This is a long time for such a risky and uncertain production activity. The capital wage time for pacu production is shorter than three years, which is considered a short payback time and consequently a period of higher liquidity Chabalin \& Neves (1997). The internal pay-back rate (IPR) for the project was $9 \%$ per year. Since the current rate of saving account interest is $6 \%$ per year, the aquaculture project is attractive because it offers a higher return. However, these results were lower than those reported by Scorvo Filho et al. (1998) for pacu and tambaqui (IPR of $27.30 \%$ year $^{-1}$ ) and carp $(23.90 \%$ year $^{-1}$ ).

Table 3 - Costs and profitability for production of piauçu ( $L$. macrocephalus) in 0.97 ha of water. Currency value date from Jan/2001.

\begin{tabular}{|c|c|c|}
\hline \multirow{3}{*}{$\begin{array}{l}\text { Income }\left(\mathrm{kg} \mathrm{cycle}^{-1}\right) \\
\text { Selling Price }\left(\mathrm{US} \$ \mathrm{~kg}^{-1}\right) \\
\text { Production Costs }\end{array}$} & \multicolumn{2}{|c|}{$20,000.00$} \\
\hline & \multicolumn{2}{|c|}{1.33} \\
\hline & $\left(\mathrm{US} \$\right.$ cycle $\left.^{-1}\right)$ & $\left(\mathrm{US} \$ \mathrm{~kg}^{-1}\right)$ \\
\hline Effective Operational Cost & $19,849.11$ & 0.99 \\
\hline Total Operational Cost & $23,237.87$ & 1.16 \\
\hline Variable Cost & $20,717.51$ & 1.04 \\
\hline Fixed Cost & $7,000.47$ & 0.35 \\
\hline Total Production Cost & $27,717.98$ & 1.39 \\
\hline Profitability & $\left(\mathrm{US} \$ \mathrm{cycle}^{-1}\right)$ & $\left(\mathrm{US} \$ \mathrm{~kg}^{-1}\right)$ \\
\hline Gross Income & $26,598.47$ & 1.33 \\
\hline Net Financial Income ${ }^{1}$ & $6,749.36$ & 0.34 \\
\hline Net Income ${ }^{2}$ & $3,360.59$ & 0.17 \\
\hline Earnings ${ }^{3}$ & $-1,119.51$ & -0.06 \\
\hline
\end{tabular}

${ }^{1}$ Net Financial Income $=$ Gross Income - Effective Operational Cost ${ }^{2}$ Net Income $=$ Gross Income - Total Operational Cost

${ }^{3}$ Earnings $=$ Gross Income - Total Production Cost 


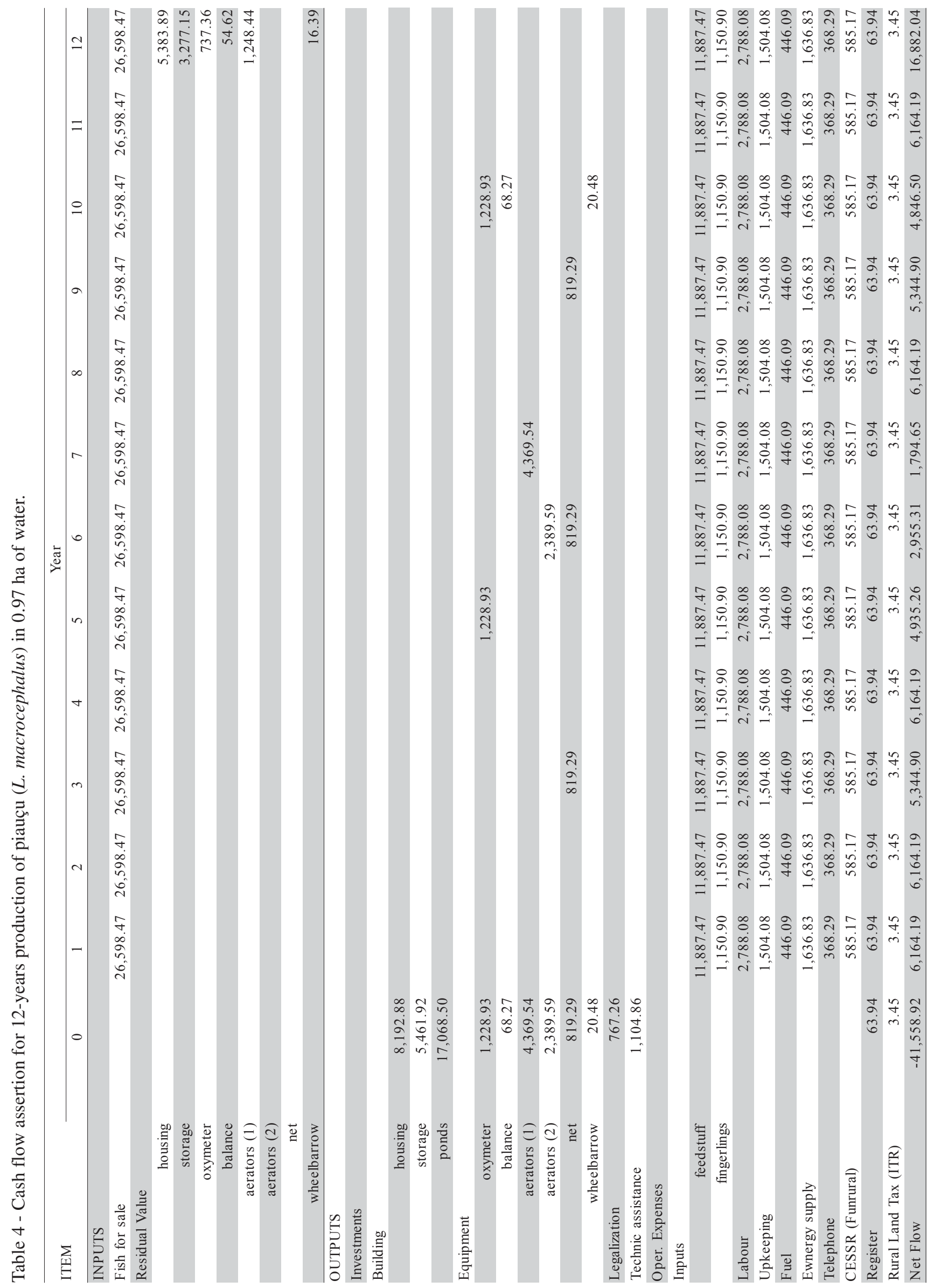


Table 5 - Capital payback period (CPP), net present value (NPV), internal return rate (IRR) and benefit-cost ratio (BCR) for the four sensitivity analyses (SA1, SA2, SA3 and SA4) for piauçu (L. macrocephalus) production.

\begin{tabular}{lcccc}
\hline & CPP & NPV & IRR & BCR \\
\hline & years & US\$ & $\%$ & \\
Actual & 8.3 & 291,07 & 9 & 1.01 \\
AS1 & 10.6 & $-8,084.29$ & 5 & 0.81 \\
AS2 & 7.5 & $4,846.54$ & 11 & 1.12 \\
AS3 & 10.9 & $-8,895.90$ & 5 & 0.79 \\
AS4 & 5.8 & $13,490.53$ & 14 & 1.32 \\
\hline
\end{tabular}

The net present value (NPV), which is the net updated return during the whole project, was positive, indicating that this activity might bring some earnings for the fish farmer in a 12-year horizon, although these are lower. The benefit to cost ratio (BCR), close to 1.0, indicates this project as unattractive investment with costs very close to the benefits.

In the sensitivity analysis 1 , where feeding expenses increased $10 \%$, the viability indicators of this project became completely unfavorable, because payback was increased and IRR decreased to 5\%; NPV became negative and BCR was lower than 1.0. Thus, feeding expenses increased by $10 \%$ turned the project not viable. In analysis 2, with decreasing feeding expenses to $5 \%$, indicators improved and became more attractive. In analysis 3 , a $5 \%$ decrease in the fish selling price led to a not viable project.

As a last simulation, the impact of technical assistance was analyzed. While this service increased the operational expenses to US\$ 1,104.86 year $^{-1}$, it also improved productive parameters and FCR to 1.9 and survival rate to $85 \%$, resulting in decreasing feeding expenses and increasing production. Thus, the viability indicators improved: payback decreased to 5.8 years; NPV reached US\$ 13,490.53; IRR became 14\% and BCR 1.32. These improvements make the piauçu fish farm more attractive activity than that reported in the case study.

\section{REFERENCES}

ANTONIALLI, L.M.; GALAN, V.B. Evolução tecnológica e competitividade de uma pequena empresa rural que atua em pecuária leiteira. Cadernos de Administração Rural, v.9, p.73-90, 1997.
CARNEIRO, P.C.F.; MARTINS, M.I.E.G.; CYRINO, J.E.P. Estudo de caso da criação comercial de tilápia vermelha em tanques-rede: avaliação econômica. Informações Econômicas, v.29, p.52-61, 1999.

CHABALIN, E.; NEVES, E.M. Análise econômica da criação de pacu sob condições de risco. In: CONGRESSO BRASILEIRO DE ECONOMIA E SOCIOLOGIA RURAL, 35., Natal, 1997. Anais. Natal: SOBER, 1997.

GITMAN, L. Princípios de administração financeira. 7.ed. São Paulo: Harbra, 1997. 841p.

HERMES, C.A.; OLIVEIRA, L.G.; MINOZZO, M.; VAZ, S.K.; MARTINS, R.S. Gerenciamento de propriedades piscícolas: apuração de custos para a produção de tilápias (Oreochromis niloticus) na região Oeste do Estado do Paraná. (Compact disc). In: SIMPÓSIO BRASILEIRO DE AQUICULTURA, 11., Florianópolis, 2000. Anais... Florianópolis: Associação Brasileira de Aquicultura, 2000.

HOLANDA JR., E.V.; RIBEIRO, L.P.; ALT, V.B.R.; HOLANDA, E.D.; MIRANDA, M.O.T. Análise de viabilidade financeira de projetos de piscicultura. Informe Agropecuário, v.21, p.10-15, 2000.

HOLANDA JR., E.V.; HOLANDA, E.D.; MADALENA, F.E.; AMARAL, J.B.C.; MIRANDA, W.M. Viabilidade financeira da pasteurização lenta de leite na fazenda:estudo de caso. Arquivos Brasileiros de Medicina Veterinária e Zootecnia, v.54, p.68-74, 2002.

INSTITUTO DE ECONOMIA AGRICOLA DO ESTADO DE SÃO PAULO. www.iea.sp.gov.br. (15/05/2002).

KUBITZA, F. Planejamento da produção de peixes. 3.ed. Jundiaí: O autor, 1999. $77 \mathrm{p}$.

LEITE, D.M.G.; COSTA, O.A.D.; VARGAS, G.A.; MILLEO, R.D.S.; SILVA, A. Análise econômica do sistema intensivo de suínos criados ao ar livre. Revista Brasileira de Zootecnia, v.30, p.482-486, 2001.

MANCIO, A.B.; SCHIFFLER, E.A.; LONDOÑO HERNÁNDEZ, F.I. Eficiência técnica e econômica de quatro empresas de produção de leite da região de São Carlos, SP. Arquivos Brasileiros de Medicina Veterinária e Zootecnia, v.51, p.283-286, 1999.

MARTIN, N.B.; SCORVO FILHO, J.D.; SANCHES, E.G.; NOVATO, P.F.C.; AYROSA, L.M.S. Custos e retornos na piscicultura em São Paulo. Informações Econômicas, v.25, p.9-47, 1995.

MATSUNAGA, M.; BEMELMANS, P.F.; TOLEDO, P.E.N.; DULLEY, R.D.; OKAWA, H.; PEDROSO, I.A. Metodologia do custo de produção adotado pelo IEA. Agricultura em São Paulo, v.23, p.123-139, 1976.

NORONHA, J.F. Projetos agropecuários: administração financeira, orçamentação e avaliação econômica. São Paulo: FEALQ, 1981. 274p.

OLIVEIRA, T.B.A.; FIGUEIREDO, R.S.; OLIVEIRA, M.W.; NASCIF, C. Índices técnicos e rentabilidade da pecuária leiteira. Scientia Agricola, v.58, p.687-692, 2001.

SCORVO FILHO, J.D. Aspectos econômicos da piscicultura de água doce com ênfase na cadeia produtiva. In: SIMPÓSIO SOBRE MANEJO E NUTRIÇÃO DE PEIXES, 2., Piracicaba, 1998. Anais. Piracicaba: CBNA, 1998. p.21-34.

SCORVO FILHO, J.D.; MARTIN, N.B.; AYROSA, L.M.S. Piscicultura em São Paulo: custos e retornos de diferentes sistemas de produção na safra 1996/97. Informações Econômicas, v.28, p.41-60, 1998.

ZYLBERSZTAJN, D. (Coord.) Agribusiness. Porto Alegre: Ortiz, 1993. 229 p.

Received November 18, 2002

Accepted January 28, 2004 